\title{
Antimicrobial and antibiofilm activity of Cymbopogon flexuosus essential oil microemulsions ${ }^{1}$
}

\author{
Karine Angélica Dalla Costa ${ }^{2}$ Renata Moura ${ }^{3}$, Alessandra F. Millezi $i^{3 *}$ (iD) \\ 10.1590/0034-737X201966050006
}

\begin{abstract}
The objective of the study was to determine the antimicrobial activity antibiofilm and to identify the main components of the essential oil (EO) obtained from the leaves of Cymbopogon flexuosus. The antibacterial and antibiofilm activity was determined against Staphylococcus aureus ATCC 29213, Pseudomonas aeruginosa ATCC 27853, Salmonella Typhimurium ATCC 14028 and Listeria monocytogenes ATCC 19117. The effect of EO on biofilm was evaluated by quantifying viable cell number (CFU) and biomass by crystal violet (CV) analysis. The composition of the essential oils was determined by GC / FID and GC / MS. The results showed action against L. monocytogenes, S. aureus and S. Typhimurium with MIC and MBC values of $3.9 \mu \mathrm{L} \mathrm{mL}^{-1}$, thus showing satisfactory antimicrobial activity, given this was the lowest concentration tested. For the antibiofilm activity, a significant reduction $(\mathrm{P}<0.05)$ was observed for $S$. typhimurium and $S$. aureus. Biofilm biomass significantly reduced only for S. aureus and P. aeruginosa. EO presented the geranial and neral isomers as major components.
\end{abstract}

Keywords: biofilm; plants antibacterial; disinfectant; secondary plant metabolism; bacterial pathogens.

\section{INTRODUCTION}

In recent decades, studies on bacterial biofilms have been growing. These dynamic communities called biofilms consist of aggregates of microorganisms encased in a polysaccharide extrapolymer matrix called an exopolysaccharide (Donlan, 2002). In both natural and artificial environments, biofilms that are embedded in an aqueous fluid are subject to hydrodynamic forces. (HallStoodley et al., 2004).

The association of bacteria in biofilms differs significantly from those that are planktonic, as they demonstrate high resistance to antimicrobials, antibiotics and sanitizers. Parallel to this, they can also deceive the system of living hosts when they attack them. (Donlan, 2002; Donlan \& Costerton, 2002). The adherence of bacterial species to surfaces used in the food industry (stainless steel and polypropylene) can have the prospect of causing problems in these environments, especially the bacteria Pseudomonas aeruginosa (Donlan 2002; Oliveira et al., 2012; Dalla Costa et al., 2016).

In view of the cellular properties of sessile bacteria, it is of great interest that new substances be developed to inhibit from the initial process of biofilm formation, thus preventing reaching the mature and most resistant stage (Junker \& Clardy, 2007; Nguyen et al., 2012). Due to the emergence of bacterial strains resistant to most of the available antimicrobials, there is a renewed interest in the search for alternative antimicrobial agents (Nascimento $e t$ al., 2000; Xiaofeng et al., 2018). Moreover, the use of synthetic preservatives, many of them with carcinogenic and teratogenic activity, has diminished their acceptance by consumers (Nascimento et al., 2000, Moreira et al., 2005).

\footnotetext{
Submitted on April $12^{\text {th }}, 2019$ and accepted on September 07 $7^{\text {th }}, 2019$.

${ }^{1}$ The work is part of the experiments related to the project. MCT / CNPq No. 14/2013 - Universal - Number 476722/2013-6.

${ }^{2}$ Universidade Regional e Integrada do Alto Uruguai e da Missões, Erechim, Rio Grande do Sul, Brazil. karinedallacosta@hotmail.com

3 Instituto Federal Catarinense, Laboratório de Biologia, Concórdia, Santa Catarina, Brazil. renatamoura85@gmail.com; alessandra.millezi@ifc.edu.br

*Corresponding author: alessandra.millezi@ifc.edu.br
} 
It is important to highlight the consumer's search for the availability of natural foods that may bring some health benefits. These factors have contributed to increasing interest in the research of natural products that present biological activity antimicrobial. Plants rich in essential oils (EOs) can be used in foods to confer flavor, aroma, and pungency, in addition to having antioxidant activity, antimicrobial and nutritional properties. Besides these properties, antibacterial activity on biofilms has been observed, aiming at the possible use of these secondary metabolites or their constituents as sanitizers (Burt, 2004; Moreira et al., 2005; Millezi et al., 2012, Xiaofeng, et al, 2018).

Among the EOs that have been in great demand throughout the world is the EO of the leaves of Cymbopogon flexuosus (lemongrass of East India or lemongrass). This fact, due to its varied range of applications in different types of industries, stands out for its lemon flavor of food and beverages, where it is used as a medicinal, condimental and/or preservative agent (Kumar et al., 2009). The objective of this study was to characterize the chemical constitution, antimicrobial and antibiofilm activity of EO obtained from leaves of Cymbopogon flexuosus.

\section{MATERIALAND METHODS}

\section{Local and period of the experiment}

Essential oil antimicrobial activity and antibiofilm were carried out in the Laboratory of Food Microbiology and Bromatology at the Federal Institute Catarinense, Concórdia, Santa Catarina, Brazil. The chemical composition characterization was carried at the Laboratory of Physical Chemistry of Embrapa Suínos e Aves, Concórdia, Santa Catarina, Brazil.

\section{Essential oil (EO)}

The essential oil extracted by hydro-distillation from leaves of Cymbopogon flexuosus were purchased from Ferquima Indústria e Comércio Ltda. (Vargem Grande, São Paulo, Brazil). For CG analysis, a solution was prepared by dissolving $100 \mathrm{mg}$ of $\mathrm{EO}$ in $10 \mathrm{ml}$ of $\mathrm{CH}_{2} \mathrm{Cl}_{2}$. These products had their quality parameters (purity, color, odor, density and refractive index at $20^{\circ} \mathrm{C}$ ) described in a report sent by the company.

\section{Gas chromatography with flame ionization detection (GC-FID)}

The EOs were analyzed using an Agilent 7820A gas chromatograph system (Agilent Technologies, Inc., Shanghai, China) equipped with a split/splitless injector, a flame ionization detector (FID), and an Agilent 7693A autoinjector. The sample solution $(1 \mu \mathrm{l})$ was injected in the split mode at a ratio of 1:10. Analyses were performed with an Agilent J\&W HP-5 capillary column ( $30 \mathrm{~m}$ x $0.25 \mathrm{~mm}$ i.d., 1 ìm film thickness, and stationary phase consisting of 5\% diphenyl/95\% dimethylpolysiloxane). The oven temperature program was as follows: held at $50{ }^{\circ} \mathrm{C}$ for 2 minutes, increased from 50 to $220^{\circ} \mathrm{C}$ at a rate of $2{ }^{\circ} \mathrm{C} / \mathrm{min}$, held at $220^{\circ} \mathrm{C}$ for 3 minutes. Nitrogen was used as carrier gas at a flow rate of $1.2 \mathrm{ml} / \mathrm{min}$. The injector and FID temperatures were fixed $240{ }^{\circ} \mathrm{C}$ and $280^{\circ} \mathrm{C}$, respectively. The flow rates of air, $\mathrm{H}_{2}$, and $\mathrm{N}_{2}$ in the FID were 300, 30, and $30 \mathrm{ml} / \mathrm{min}$, respectively. The OpenLAB CDS software was used for equipment management and data processing. The compositions of the essential oils were expressed as a percentage of normalized area.

\section{Gas chromatography coupled to mass spectrometry (GC-MS)}

The essential oils were analyzed using a Shimadzu GCMS-QP2010 gas chromatograph mass spectrometer (Shimadzu Corporation Technologies, Inc., Tokyo, Japan) equipped with a split/splitless injector. The sample solution $(1 \mu \mathrm{l})$ was injected in the split mode at a ratio of 1:10. Analyses were performed with a Supelco Equity-5 capillary column (30 m x $0.2 \mathrm{~mm}$ i.d., $0.2 \mu \mathrm{m}$ film thickness, and stationary phase consisting of 5\% diphenyl/95\% dimethylpolysiloxane). The oven temperature program was as follows: held at $50^{\circ} \mathrm{C}$ for 2 minutes, increased from 50 to $220^{\circ} \mathrm{C}$ at a rate of $2{ }^{\circ} \mathrm{C} / \mathrm{min}$, and held at $220^{\circ} \mathrm{C}$ for 3 minutes. Helium was used as carrier gas at a flow rate of $1.2 \mathrm{ml} / \mathrm{min}$ (constant linear velocity of $39.2 \mathrm{~cm} / \mathrm{sec}$ ). The injector temperature was set at $240^{\circ} \mathrm{C}$. The interface and ion source temperatures were fixed at 220 and $200{ }^{\circ} \mathrm{C}$, respectively. Quadrupole mass spectrometer was operated in electron impact mode at 70 e V, scanning the range $\mathrm{m} / \mathrm{z} 35-350$ in cycles of $0.5 \mathrm{~s}$. The GCMS solution software was used for equipment management and data processing. Compounds were identified by searching the NIST 05 mass spectral library and by comparison of their retention indices relative to C7-C30 n-alkane series with those values found in an online database (El-Sayed, 2018).

\section{Bacterial strains and standardization}

The species Staphylococcus aureus ATCC 29213, Pseudomonas aeruginosa ATCC 27853, Salmonella Typhimurium ATCC 14028 and Listeria monocytogenes ATCC 19117 were obtained from the Oswaldo Cruz Foundation (FIOCRUZ), Rio de Janeiro, Brazil. Bacteria were incubated in Tryptic Soy Broth (TSB) (Sigma, India) medium overnight at $37{ }^{\circ} \mathrm{C}$ after calculations for the inoculation determined. The standardization of the number of cells was determined by a growth curve absorbance at $630 \mathrm{~nm}$ and $\mathrm{CFU} \mathrm{mL} \mathrm{m}^{-1}$ were measured until approximately $10^{8} \mathrm{CFU} \mathrm{mL}^{-1}$. 


\section{Minimal Inhibitory Concentration (MIC)}

Minimal Inhibitory Concentration (MIC) was detected by the microdilution method with adaptations (NCCLS/ CLSI, 2003). The results were expressed in $\mu \mathrm{L} \mathrm{mL}^{-1}$. The essential oil was diluted at concentrations $50 \mu \mathrm{L} \mathrm{mL}^{-1}$ to $3.9 \mu \mathrm{L} \mathrm{mL}^{-1}$ in Brain Heart Infusion - BHI (Himedia, China) broth medium with $0.5 \%$ tween 80 in the wells of the microdilution plates. Subsequently, $90 \mu \mathrm{l}$ of the BHI culture medium and finally $10 \mu \mathrm{L}$ of the adjusted bacterial suspension were added at a concentration of approximately $10^{8} \mathrm{CFU} \mathrm{mL}^{-1}$.

In each line, sterility controls (BHI broth with $0.5 \%$ tween 80 added with BHI and without the addition of inoculum) and growth controls (BHI broth with $0.5 \%$ tween 80 added with BHI and inoculum) were maintained. The plates were incubated at $36^{\circ} \mathrm{C}$ for $18 \mathrm{~h}-24 \mathrm{~h}$ and microbial growth was visually detected and confirmed by the addition of $20 \mu \mathrm{l}$ of $0.5 \%(\mathrm{~m} / \mathrm{v})$ aqueous triphenyl-tetrazolium chloride (TTC) solution, with additional incubation of $1 \mathrm{~h}$, at the same temperature. The MIC was defined as the lowest concentration of each extract that totally inhibited microbial growth.

\section{Minimum bactericidal concentration (MBC)}

The minimum bactericidal concentration of the $\mathrm{EO}$ was determined from the plates used for the determination of the MIC, through a methodology adapted from Celiktas $e t$ al., 2007. From each well where no microbial growth occurred, $10 \mathrm{i} \mathrm{L}$ was transferred to TSA plates. Plates were incubated at $36^{\circ} \mathrm{C}$ for $24 \mathrm{~h}$ and colony growth was checked. The MBC was defined as the lowest concentration of EO lemongrass, which totally prevented the microbial growth in the plaques.

\section{Antibiofilm activity}

For biofilm formation, inoculation was performed at approximately $10^{8} \mathrm{CFU} \mathrm{mL}^{-1}$ (in the calibration curve) in 96well polypropylene microplates. The EO and the bacterial inoculum in a ratio of $1: 1(\mathrm{v} / \mathrm{v})$ were added in triplicate. To prepare the EO dilutions, $2 \%$ DMSO and $0.85 \%$ saline water plus $0.5 \%$ tween 80 were used as diluting solutions, a $2.5 \%$ stock dilution whose concentrations were: $0.195 \%, 0.39 \%$ and $0.78 \%$ in TSB medium supplemented with $0.5 \%$ tween 80 (Millezi et al., 2016 with modifications).

In addition, the treatments with oils inoculated also in triplicate the positive control $(0,0 \%$ of $\mathrm{EO})$ containing the bacterial inoculum and the TSB broth $(1: 1 \mathrm{v} / \mathrm{v})$, the negative control only EO and TSB medium (1:1 v/v) and white (only one TSB medium). Afterward, the microplate for the orbital was sent to the agitator (Tecnal, Brazil) and shaken at $37^{\circ} \mathrm{C}$ at $80 \mathrm{rpm}$ for $24 \mathrm{~h}$ (Millezi et al., 2016). This procedure was also performed for analyses of Biomass Quantification and Quantification of Viable Cells after $24 \mathrm{~h}$.

\section{Crystal Violet Analysis (CV)}

Biomass biofilms were quantified by adapting the crystal violet (CV) staining method by Stepanovic et al. (2000) and after 24 hours of incubation, the untreated control, containing only culture medium and the bacterial inoculum, were used to classify the bacteria as biofilm formation capacity. For fixing, we added $200 \mu 1$ of $99 \%$ methanol (Vaz Pereira, Portugal) to each well containing adhered cells or biofilms treated with essential oils, as previously described. After the time of 15 minutes, the methanol was removed and the polystyrene microplates were allowed to dry at room temperature. Then $200 \mu 1$ of $\mathrm{CV}$ stain $(1 \% \mathrm{v} / \mathrm{v})$ (Merck, Portugal) was added to all wells. After 5 minutes, $\mathrm{CV}$ excess was removed and plates were washed in distilled water. Finally, $230 \mu \mathrm{l}$ of acetic acid $(33 \% \mathrm{v} / \mathrm{v})$ (Pronalab, Portugal) were added to the wells to dissolve $\mathrm{CV}$ stain, and the absorbance was measured at $630 \mathrm{~nm}$ in spectrophotometer Elisa (Biotek, USA).

The design of the analysis followed in three replications and triplicate.

\section{Quantification of colony forming units (CFU) in biofilm}

For the quantification of colony forming units (CFUs) in biofilm, microwells where the crops were washed in sterile water to remove planktonic bacteria $200 \mu$ sterile distilled water was added to the wells and viable biofilm cells were removed by sonication ( 6 minutes) and then serial dilution of samples. The plating of the sample aliquots was then plated on TSA (Trypan Soy Agar, Acumedia) medium, and plates were incubated at $37^{\circ} \mathrm{C}$ in an aerobic incubator for $18 \mathrm{~h}$ prior to enumeration. The number of cultivable bacterial cells was determined and expressed as Log CFU $\mathrm{cm}^{-2}$ and three repliactions.

\section{Statistical analysis}

Statistical analysis was performed using Prism version 3.0 (GraphPad Software, Inc., La Jolla, USA). The assumptions for the parametric test were checked before the analysis. Data was analyzed One-way ANOVA Bonferroni test was performed and $\mathrm{P}<0.05$ was considered significant. The analyses were performed in triplicate and assays were performed on three separate occasions.

\section{RESULTS AND DISCUSSION}

\section{Identification and quantification of $\mathrm{EO}$ constituents}

A total of 19 different components were identified in $C$. flexuosus $\mathrm{EO}$ (Table 1). The results obtained showed that geranial was the predominant component, representing $41.80 \%$, followed by neral $33.25 \%$. 
The $C$. flexuosus plant, popularly known as lemongrass is widely used as a medicinal and condimentar plant. This use is not random, this plant has compounds that confer biological properties, antioxidant and antimicrobial, as it is the case of EOs, secondary plant metabolites that are addressed in some studies (Rota et al., 2008; Sharma et al., 2009; Xiaofeng et al., 2018) and especially in this research, which describes results on its constitution and antibacterial activity.

Several factors such as temperature, light intensity, soil moisture, fertilizers, and developmental stages of the plant/ parts greatly influence the EO content and the composition of lemongrass (Ganjewala et al., 2008). EO production is dependent on the early growth stages of leaf and inflorescence, respectively (Singh et al., 1989). In general, EO production is directly proportional to the yield of the biomass of the plant/plant parts. In lemongrass, younger leaves produce $\mathrm{EO}$ of higher quality with very high citral content $(75 \%)$, where as older leaves have a low level of citral when harvested at a given point. Lemongrass EO consists mainly of citral, a mixture of geranial and neral isomers (40\% and 32\% respectively) (Ganjewala \& Gupta, 2013). In this study, the proportions were $41.8 \%$ geranial and $33 \%$ general, corroborating with the literature.

\section{Antimicrobial activity}

The results showed action against $S$. aureus, $S$. Typhimurium and L. monocytogenes, with MIC and MBC values $3.9 \mu \mathrm{L} \mathrm{mL}^{-1}$ showing satisfactory antimicrobial activity (Table 2) because this was the lowest concentration tested. None of the concentrations were efficient to inhibit $P$. aeruginosa, so the cells with the highest concentration

Table 1: Chemical composition (\%) of essential oils from Cymbopogon flexuosus

\begin{tabular}{|c|c|c|c|}
\hline Compound $^{\mathrm{a}}$ & $\mathbf{R I}^{\mathbf{b}}$ & RIE $^{c}$ & C.flexuosus (\%) \\
\hline$\alpha$-Pinene & 939 & 920 & 0.15 \\
\hline Camphene & 954 & 935 & 0.79 \\
\hline 6-Methyl-5-hepten-2-one & 985 & 985 & 1.66 \\
\hline$\beta$-Myrcene & 990 & 989 & 0.37 \\
\hline D-Limonene & 1030 & 1025 & 0.27 \\
\hline$(Z)$ - $\beta$-Ocimene & 1040 & 1036 & 0.19 \\
\hline$(E)$ - $\beta$-Ocimene & 1050 & 1046 & 0.13 \\
\hline 4-Nonanone & 1053 & 1072 & 0.59 \\
\hline$\beta$-Linalool & 1100 & 1101 & 1.54 \\
\hline Isopulegol & 1145 & 1143 & - \\
\hline Citronellal & 1153 & 1152 & 0.23 \\
\hline 4,5-Epoxy- $t$-carene & - & 1182 & 1.04 \\
\hline$\alpha$-Terpeniol & 1185 & 1189 & 0.61 \\
\hline$\beta$-Citronellol & 1228 & 1231 & - \\
\hline Neral & 1238 & 1240 & 33.25 \\
\hline Geraniol & 1253 & 1259 & 5.37 \\
\hline Geranial & 1267 & 1270 & 41.80 \\
\hline Citronellyl acetate & 1353 & 1352 & - \\
\hline Geranyl acetate & 1383 & 1382 & 4.23 \\
\hline$\beta$-Elemene & 1391 & 1386 & - \\
\hline$\beta$-Caryophyllene & 1419 & 1410 & 2.01 \\
\hline$\gamma$-Muurolene & 1477 & 1505 & 1.07 \\
\hline$\alpha$-Muurolene & 1499 & 1494 & - \\
\hline$\delta$-Cadinene & 1524 & 1516 & 0.42 \\
\hline Elemol & 1547 & 1544 & - \\
\hline Geranyl butyrate & 1562 & 1570 & - \\
\hline Nerolidol & 1564 & 1576 & - \\
\hline Monoterpenes hydrocarbons & & & 1.89 \\
\hline Oxygenated monoterpenes & & & 83.85 \\
\hline Sesquiterpenes hydrocarbons & & & 3.50 \\
\hline Oxygenated sesquiterpenes & & & - \\
\hline Others & & & 6.49 \\
\hline Total identified & & & 95.72 \\
\hline
\end{tabular}

\footnotetext{
${ }^{a}$ Compounds are listed in order of their elution from a Supelco Equity-5 column (30 m, $0.2 \mathrm{~mm}, 0.2$ ìm)

${ }^{\mathrm{b}}$ Retention index obtained at http://www.pherobase.com/

${ }^{c}$ Retention index experimentally determined on a Supelco Equity-5 column, using a homologous series of C7-C30 alkanes
} 
$\left(500 \mu \mathrm{L} \mathrm{mL}^{-1}\right)$ were counted in comparison with the positive control, in which a viable cell reduction of 1.6 CFU Log 10 $\mathrm{mL}$.

The bioactive potential of lemongrass oil and constituents are rapidly increasing, which is reflected in the growing number of reports being published. Since lemongrass oil is easily available, non-toxic safe and has a pleasant aroma, it is becoming increasingly popular among pharmaceuticals, cosmetic and medicines. The chemical properties of the lemongrass oil have been promising in the integrated pest management program, as this property may lead to the development of alternatives promising, being more natural and desirable than synthetic chemical pesticides (Kumar et al., 2007). Most of the bioactivities of lemongrass oil has been attributed to its one or more major chemical constituents, namely neral and geranial (Santoro et al., 2007; Kumar et al., 2007; Sharma et al., 2009).

\section{Crystal Violet Analysis (CV)}

The studies to verify the adhesion capacity of the bacteria in the polyethylene plates showed that and $P$. aeruginosa adhered strongly, proving the biofilm formation in 24 hours of culture. Salmonella Typhimurium and Listeria monocytogenes were classified as weakly biofilm (Table 3).

Table 2: Minimum Inhibitory Concentration (MIC) and Minimum Bactericidal Concentration (MBC) of Cymbopogon flexuosus $\mathrm{EO}\left(\mu \mathrm{L} \mathrm{mL}^{-1}\right)^{\mathrm{a}}$

\begin{tabular}{|c|c|c|}
\hline & MIC & MBC \\
\hline \multicolumn{3}{|c|}{ Gram-positive bactéria } \\
\hline Staphylococcus aureus ATCC 29213 & 3,90 & 3,90 \\
\hline Listeria monocytogenes ATCC 19117 & 3,90 & 3,90 \\
\hline \multicolumn{3}{|l|}{$\begin{array}{ll}\text { Gram-negative bactéria } \\
\end{array}$} \\
\hline Salmonella Typhimurium ATCC 14028 & 3,90 & 3,90 \\
\hline Pseudomonas aeruginosa ATCC 27853 & $>50$ & $>50$ \\
\hline
\end{tabular}

a The tests were performed in triplicate and the modal values are presented

Table 3: Adhesion ability of bacterial species strains to microplates polystyrene according to the classification proposed by Stepanovic et al. (2000)

\begin{tabular}{lc}
\hline Bacterial species & Adhesion after $\mathbf{2 4} \mathbf{~ h}$ \\
\hline Staphylococcus aureus & +++ \\
Pseudomonas aeruginosa & +++ \\
Salmonella Typhimurium & + \\
Listeria monocytogenes & + \\
+ , ODc < OD d" 2 ODc, weakly adherent/weak biofilm producer; & + \\
,$++ 2 \mathrm{ODc}<\mathrm{ODd}$ " $4 \mathrm{xODc}$, moderately adherent/moderate biofilm \\
producer; +++, 4xODc < OD, strongly adherent/strong biofilm \\
producer; where OD is the optical density of the negative control \\
and ODc is the cut-off OD value defined as three standard deviation \\
values above the mean OD of the negative control.
\end{tabular}

The EO effect on $S$. aureus biomass was efficient, with a significant reduction $(\mathrm{P}<0.05)$ for all concentrations (figure 1A). Listeria monocytogenes and S. Typhimurium showed to be weakly adherent (figure 1B e 1D), however, the EO demonstrated significant activity against adherence (P < 0.05) of $S$. Typhimurium. Pseudomonas biomass, presented a significant reduction $(\mathrm{P}<0.05) 67.13 \%$ in the concentration $0.39 \%$ and $0.195 \%$ (57.8\%) (Figure 1C).

The antibiofilm activity investigated EOs and extracts of pepper mint (Mentha x Piperita L.), coriander (Coriandrum sativum L.) and anise (Pimpinella anisum L.) against Gram-positive bacteria (S. aureus) and Gramnegative (E. coli) (Bazargani \& Rohloff, 2016). The authors performed the minimum inhibitory concentration (MIC) using the double-series dilution method. The antimocrobial activity was observed for almost all plant extracts and EOs against both bacterial strains with stronger activity against S. aureus, again observing the greater resistance to Gramnegative species. All EOs had MIC values of 0.8 to $0.63 \mu \mathrm{L}$ $\mathrm{mL}^{-1}$ and 8 of 14 plant extracts of 2 and $4 \mu \mathrm{L} \mathrm{mL}^{-1}$ for both bacteria. The $\mathrm{CV}$ and XTT reduction assays demonstrated inhibition of bacterial fixation by at least $50 \%$ for coriander $\mathrm{EO}$, indicating further investigations due to the high activity potential of this oil.

In our study, there was a satisfactory reduction of biofilm biomass, suggesting rupture of the structure, however, the viable cells were not significantly reduced, thus allowing the cells to produce the exopolysaccharides again and reconstitute the biofilm structure. Only Salmonella cells were significantly reduced at all concentrations. The $0.78 \%$ concentration was efficient in the reduction of viable cells in $S$. aureus biofilm, the treatment time parameter and the temperature factor is variables to be tested in order to reduce the viable cells.

\section{Quantification of colony forming units (CFU) in biofilm}

Quantification of viable cells in biofilm demonstrated that only $S$. Typhimurium was significantly reduced in the OE treatments at the three concentrations $(\mathrm{P}>0.05)$. Staphylococcus aureus was significantly reduced only at the concentration of $0.78 \% \quad(\mathrm{P}<0.05)$. Listeria monocytogenes and Pseudomonas aeruginosa were resistant at all concentrations ( $\mathrm{P}>0.05)$ (Figure 2).

In some cases, the activity of the compound alone is not always more efficient than that of EO. In a study by Millezi et al. (2016), EOs treatments of palmarosa, cinnamon, and green tea, as well as their respective major compounds, respectively, geraniol, eugenol, and terpine-4-ol, reduced planktonic and biofilm populations of $S$. aureus and $E$. coli, however, EOs proved to be more efficient. The activity of antibacterial substances varies according to some types of bacteria and arrangements. Bacteria in the planktonic 
state are more sensitive than strongly adhered bacteria forming biofilms. Satisfactory MIC and MBC results for planktonic bacteria may not have the same effect for bacteria of the same species in biofilms. After bacteria establish biofilms, they initiate different gene expression than free or planktonic, causing phenotype changes (Prigent-Combaret \& Lejeune, 1999). Importantly, among these changes is the greater capacity of resistance to antimicrobials. Sessile bacteria in biofilms are more resistant to physical and chemical forms of eradication, and thus cause persistent infections. (Costerton, 2005; Rota et al., 2008, Simões et al., 2018). In this way, bacterial cells in biofilms can survive and persist after cleaning and disinfection if performed inefficiently. This fact may represent a possible source of food poisoning in humans and animals, as well as problems with economic losses (Chavant et al., 2007).

The activity of EOs may be related to the capacity of current in the plasma membrane and cell wall, causing through diffusion process because they are lipophilic compounds (Bakkali et al., 2008). The complexity of the mechanism EOs action in the bacterial cell is described: cell wall destruction, plasmatic membrane damage such as protein and enzyme inactivation, interference with proton motive force, coagulation of cytoplasmic fluid (Burt 2004; Ayala-Zavala et al., 2009).

Oliveira et al., (2012) studied the antibacterial effect EO Cinnamomum cassia bark, Melaleuca alternifolia and
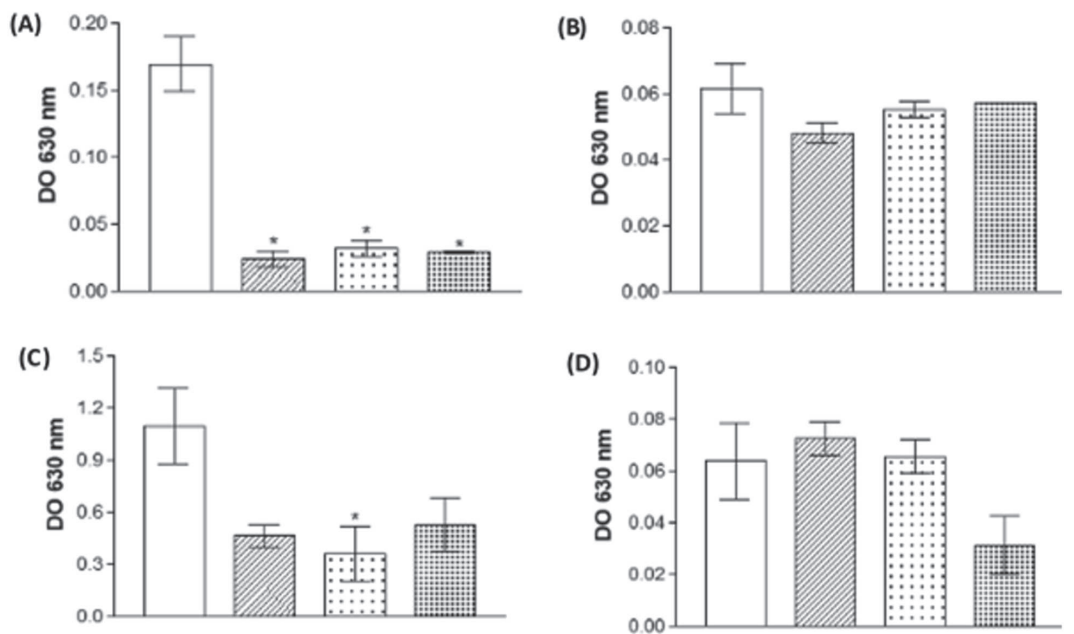

Concentrations (\%): $\square 0,0$ एवय 0,195

Figure 1: Quantification of biofilm biomass Staphylococcus aureus (A), Salmonella Typhimurium (B); Pseudomonas aeruginosa (C) e Listeria monocytogenes (D). The values are means of three assays, and the bars indicate standard deviation. $* \mathrm{P}<0.05$ in ANOVA test.
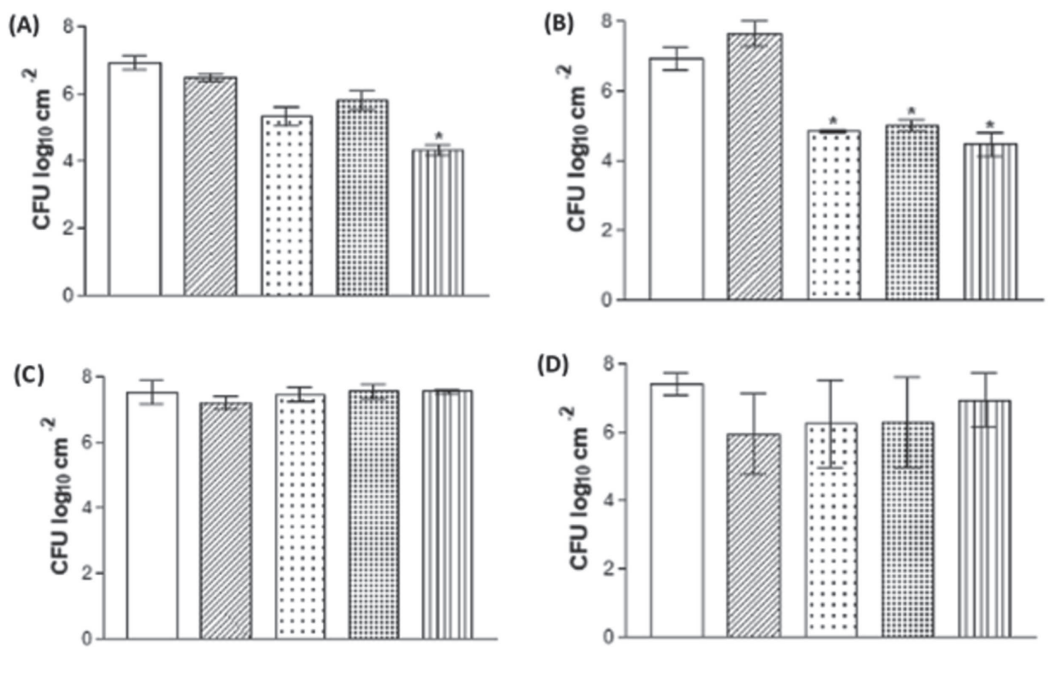

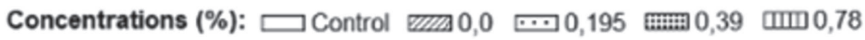

Figure 2: Quantification of viable cells in biofilm Staphylococcus aureus (A), Salmonella Typhimurium (B); Pseudomonas aeruginosa (C) e Listeria monocytogenes (D). The values are means of three separate assays, and the bars indicate standard deviation. $* \mathrm{P}<0.05$ in one-way analysis of variance test. 
C. flexuosus against E. coli and L. monocytogenes. The tests result showed antibacterial activity; however, EO of C. cassia was shown to be the most effective for biofilm control. The combination C. flexuosus and M. alternifolia presented greater efficiency than the individual one. $L$. monocytogenes has been shown to be more suitable to the action of EOs than to EPEC, which demonstrates the greater resistance of Gram-negative bacteria.

\section{CONCLUSION}

This study demonstrated that the EOs have important biological properties, therefore they should be researched and tested. Further investigations, including doseresponse and toxicological studies, are needed to establish these promising natural compounds as sanitizers in the real complex of food-processing ecosystems.

\section{DECLARATION OF CONFLICTING INTERESTS}

The Author(s) declare(s) that there is no conflict of interest.

\section{REFERENCES}

Ayala-Zavala JF, González-Aguilar GA \& Del-Toro-Sánchez L (2009) Enhancing safety and aroma appealing of fresh-cut fruits and vegetables using the antimicrobial and aromatic power of essential oils. Journal of Food Science, 74:84-91.

Bakkali F, Averbeck S, Averbeck D \& Idaomar M (2008) Biological effects of essential oils: a review. Food and Chemical Toxicology, $46: 446-75$

Bazargani MM \& Rohloff J (2016) Antibiofilm activity of essential oils and plant extracts against Staphylococcus aureus and Escherichia coli biofilms. Food Control, 61:156-64.

Burt S (2004) Essential oils: their antibacterial properties and potential applications in foods - a review. International Journal of Food Microbiology, 94:223-253.

Celiktas OY, Kocabas EEH, Bedir E, Sukan FV \& Baser KHC (2007) Antimicrobial activity of methanol extracts and essential oils of Rosmarinus officinalis, depending on location and seasonal variations. Food Chemistry, 100:553-559.

Chavant P, Gaillard-Mertinie B, Talon R, Hébraud M \& Bernardi $\mathrm{T}$ (2007) A new device for rapid evaluation of biofilm formation potential by bacteria. Journal of Microbiological Methods, 68:605-612.

Costerton JW (2005) Biofilm theory can guide the treatment of device-related orthopedic infections. Clinical Orthopaedics and Related Research, 437:07-11.

Dalla Costa KA, Ferenz M, Silveira SM \& Millezi AF (2016) Formação de biofilmes bacterianos em diferentes superfícies de indústrias de alimentos. Revista Instituto Laticínios Cândido Tostes, 71:75-82.

Donlan RM (2002) Biofilms: Microbial Life on Surfaces. Emerging Infectious Diseases, 8:881-890.

Donlan RM \& Costerton JW (2002) Biofilms: survival mechanisms of clinically relevant microorganisms. Clinical Microbiology Revision, 15:167-93.
El-Sayed AM (2018) The Pherobase: Database of Pheromones and Semiochemicals. Available at: 〈http://www.pherobase.com>. Accessed on: August 24 ${ }^{\text {th }}, 2018$.

Ganjewala D \& Gupta AK (2013) Lemongrass (Cymbopogon flexuosus Steud.) Essential Oil: Overview and Biological Activities. Recent Progresses in Medicinal Plants, 37:234-74.

Ganjewala D, Kumari A \& Khan KH (2008) Ontogenic and developmental changes in essential oil content and compositions in Cymbopogon flexuosus cultivars. In: Prasad BN \& Lazer Mathew (Eds.) Recent Advance in Biotechnology. New Delhi, Excel India Publishers. p.82-92.

Hall-Stoodley L, Costerton JW \& Stoodley P (2004) Bacterial biofilms: from the natural environment to infectious diseases. Natural Research Microbiology, 2:95-108.

Kumar R, Srivastava M \& Dubey NK (2007) Evaluation of Cymbopogon martini oil extract for control of postharvest insect deterioration in cereals and legumes. Journal of Food Protection, 270:172-178.

Kumar S, Subudhi E, Nayak S \& Sahoo S (2009) Differential citral content of 15 lemongrass genotypes and their antimicrobial property. Internet Journal of Microbiology, 6:01-08.

Junker LM \& Clardy J (2007) High-throughput screens for smallmolecule inhibitors of Pseudomonas aeruginosa biofilm development. Antimicrobial Agents and Chemotherapy, 51:3582-3590.

Millezi AF, Pereira MO, Batista NN, Camargos N, Auad I, Cardoso MDG \& Piccoli RH (2012) Susceptibility of mono and dualspecies biofilms of Staphylococcus aureus and Escherichia coli to essential oils. Journal of Food Safety, 32:351-359.

Millezi AF, Piccoli RH, Oliveira JM \& Pereira MO (2016) Antibiofilm and Antibacterial Effect of Essential Oils and Their Major Compounds. Journal of Essential Oil Bearing Plants, 19:624-31.

Moreira MR, Ponce AG, Del Valle CE \& Roura SI (2005) Inhibitory parameters of essential oils to reduce a foodborne pathogen. $y$ Food Science and Technology, 38:565-570.

Nascimento GGF, Locatelli J \& Freitas PC (2000) Antibacterial activity of plant extracts and phytochemicals on antibioticresistant bacteria. Brazilian Journal of Microbiology, 31:24756.

NCCLS/CLSI (2003) M07-A10- Methods for Dilution Antimicrobial Susceptibility Tests for Bacteria that Grow Aerobically. $6^{\text {th }}$ Edition. Wayne, NCCLS/CLSI. 87p.

Nguyen UT, Wenderska IB, Chong MA, Koteva K, Wright GD \& Burrows LL (2012) Small-molecule modulators of Listeria monocytogenes biofilm development. Applied and Environmental Microbiology, 78:1454-1465.

Oliveira MMM, Brugnera DF, Nascimento JA \& Piccoli RH (2012) Control of planktonic and sessile bacterial cells by essential oils. Food and Bioproducts Processing, 90:809-18.

Prigent-Combaret C \& Lejeune P (1999) Monitoring gene expression. In biofilms. Methods in Enzymology, 310:56-79.

Rota CM, Herrera A, Martínez RM, Sotomayor JA \& Jordán MJ (2008) Antimicrobial activity and chemical composition of Thymus vulgaris, Thymus zygis and Thymus hyemalis essential oils. Food Control, 19:681-687.

Santoro GF, Cardoso MG, Guimaraes LG, Freire JM \& Soares MJ (2007) Antiproliferative effect of the essential oil of Cymbopogon citratus (DC) Stapf (lemongrass) on intracellular amastigotes, bloodstream trypomastigotes and culture epimastigotes of Trypanosoma cruzi (Protozoa: Kinetoplastida). Parasitology, 134:1649-1656. 
Sharma PR, Mondhe DM, Muthiah S, Pal HC, Shahi AK \& Saxena AK (2009) Anticancer activity of essential oil from Cymbopogon flexuosus. Chemical-Biological Interactions, 179:160-168

Simões M, Dias C, Borge A \& Saavedra MJ (2018) Biofilm formation and multidrug-resistant Aeromonas spp. from wild animals. Journal of Global Antimicrobial Resistance, 12:227234.

Singh N, Luthra R \& Sangwan RS (1989) Effect of leaf position and age on the essential quantity and quality in lemongrass (Cymbopogon flexusosus Stapf.). Planta Medica, 55:254-256.
Stepanovic S, Vucovic D, Dakic I \& Savic B (2000) A modified microtiter-pate test for quantification of staphylococcal biofilm formation. Journal of Microbiological Methods 40:175-179.

Xiaofeng Z, Guo Y, Guo L, Jiang H \& Ji Q (2018) In Vitro Evaluation of Antioxidant and Antimicrobial Activities of Melaleuca alternifolia Essential Oil. BioMed Research International, p.0108 . 